\title{
Hanford Transuranic Storage Corrosion Review
}

J. L. Nelson

J. R. Divine

December 1980

Prepared for

Rockwell Hanford Operations under a Related Services Agreement with the U.S. Department of Energy

Contract DE-AC06-76RLO 1830

Pacific Northwest Laboratory

Operated for the U.S. Department of Energy

by Battelle Memorial Institute 


\title{
NOTICE
}

This report was prepared as an account of work sponsored by the United States Government. Neither the United States nor the Department of Energy, nor any of their employees, nor any of their contractors. subcontractors, or their employees, makes any warranty, express or implied. or assumes any legal liability or responsibility for the accuracy, completeness or usefulness of any information, apparatus. product or process disclosed, or represents that its use would not intringe privately owned rights.

The views. opinions and conclusions contained in this report are those of the contractor and do not necessarily represent those of the United States Government or the United States Department of Energy.

\author{
PACIFIC NORTHWEST LABORATORY \\ operated by \\ BATTELLE \\ for the \\ UNITED STATES DEPARTMENT OF ENERCY \\ Lnder Contract DE-AC06-76RLO 1830
}
Printed in the Lnited States of America
Available irom
Vational Technical Information Service
Lnited States Department of Commerce
5285 Port Roval Road
Springfield, Virginia 22151

Price: Printed Copy $\$$

$\therefore$ Microfiche $\$ 3.00$

VTIS

-Pages Selling Price

$001-025 \quad \$ 4.00$

026-050 $\quad \$ 4.50$

$051-075 \quad \$ 5.25$

$076-100 \quad \$ 6.00$

$101-125 \quad \$ 6.30$

126-150 5.25

$151-175 \quad \$ 8.00$

$176-200 \quad \$ 9.00$

$201-225 \quad \$ 9.25$

226-250 $\quad 59.50$

251-275 $\$ 10.75$

2v6-300 $\$ 11.00$ 


\section{2}

HANFORD TRANSURANIC STORAGE CORROSION REVIEW

J. L. Nelson

J. R. Divine

December 1980

Prepared for

Rockwell Hanford Operations under a Related Services Agreement with the U.S. Department of Energy

Contract DE-ACO6-76RLO 1830

Pacific Northwest Laboratory

Richland, Washington 99352 



\section{SUMMARY}

The rate of atmospheric corrosion of the transuranic (TRU) waste drums at the U.S. Department of Energy's Hanford Project, near Richland, Washington, was evaluated by Pacific Northwest Laboratory (PNL). The rate of corrosion is principally contingent upon the effects of humidity, airborne pollutants, and temperature.

Results of the study indicate that actual penetration of barrels due to atmospheric corrosion will probably not occur within the 20-year specified recovery period. Several other U.S. burial sites were surveyed, and it appears that there is sufficient uncertainty in the available data to prevent a clearcut statement of the corrosion rate at a specific site. Laboratory and site tests are recommended before any definite conclusions can be made.

The corrosion potential at the Hanford TRU waste site could be reduced by a combination of changes in drum materials (for example, using galvanized barrels instead of the currently used mild steel barrels), environmental exposure conditions (for example, covering the barrels in one of numerous possible ways), and storage conditions (for example, separating the layers of barrels with slats of wood instead of sheets of plywood). 


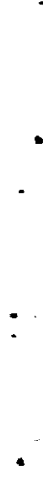


CONTENTS

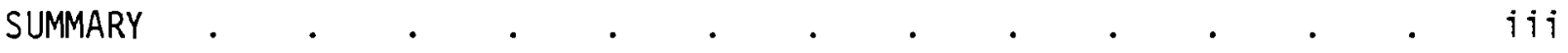

INTRODUCTION $\cdot$.

CONCLUSIONS AND RECOMMENDATIONS

SYSTEM DESCRIPTION .

FACTORS DETERMINING ATMOSPHERIC CORROSION RATES . . . . . . . 6

HUMIDITY EFFECTS •

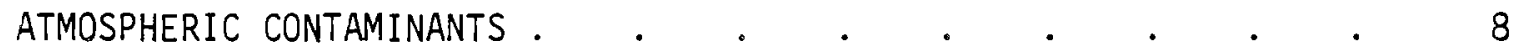

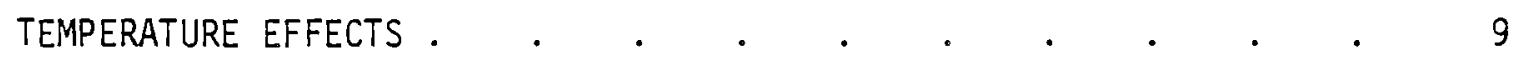

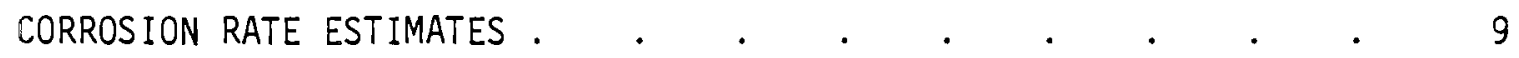

STORAGE SYSTEMS AT OTHER FACILITIES

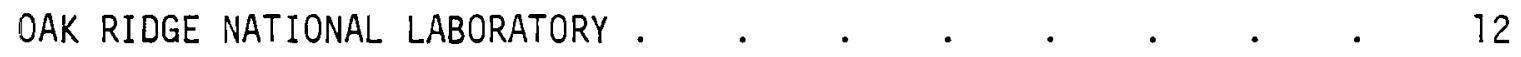

LOS ALAMOS SCIENTIFIC LABORATORY . . . . . . . . . . 12

SAVANNAH RIVER LABORATORY

IDAHO NATIONAL ENGINEERING LABORATORY . . . . . . . 13

DISCUSSIONS ON CORROSION CONTROL

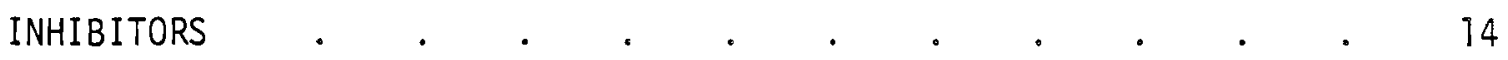

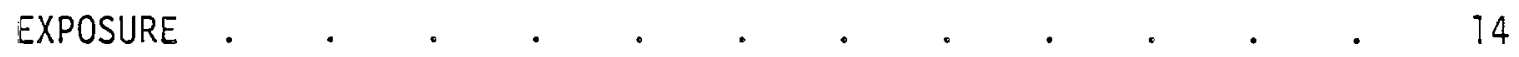

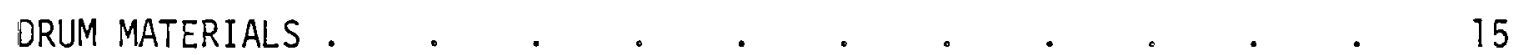

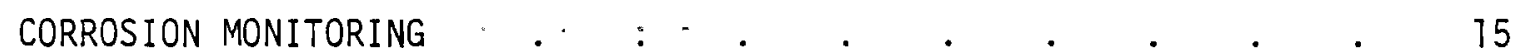

ENVIRONMENTAL CONTROL AFTER BURIAL

REFERENCES $\cdot$.

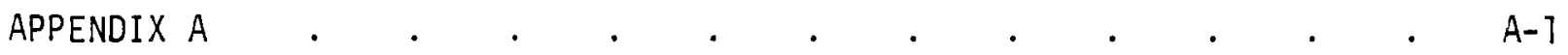

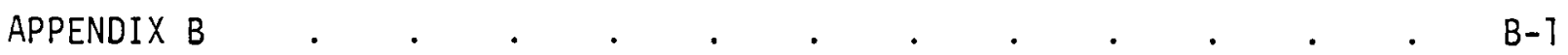

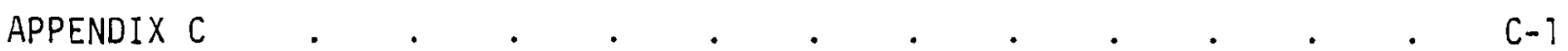




\section{FIGURES}

1. Portion of a Transuranic Waste Pad . . . . . . . . . 5

2. Weight Gain as a Function of Percent of Relative Humidity

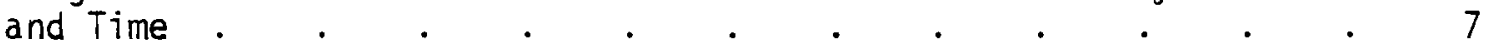

3. Conceptual Dust Shield for Transuranic Pads During Loading . . 16 


\section{INTRODUCTION}

The Hanford transuranic (TRU) waste disposal site is located in the 200 West Area in the southwestern part of the U.S. Department of Energy's (DOE) Hanford Project, near Richland, Washington. The site was established by the 1970 directive of the Atomic Energy Commission (AEC) that required that all waste contaminated with TRU isotopes be isolated from other types of radioactive waste because of its high radiotoxicity and long half-life. The TRU waste is stored in 208-1iter (55-gal) mild steel drums $(a)$ with a desired recovery period of 20 years. Barrels that were stored outdoors for 2 years show corrosion of the lids and lock rings; the interiors of the barrels were not viewed.

As part of Rockwell Hanford Operations (RHO) storage and disposal program, Pacific Northwest Laboratories $(P N L){ }^{(b)}$ was requested to determine the degree to which environmental conditions (particularly humidity) cause corrosion of the exteriors of the waste containers in TRU pad storage. The objective of this study is to review the technical literature pertinent to atmospheric corrosion of mild steel and to prepare a sumary report of the literature, including recommendations for measurements in new and existing facilities, laboratory tests, and corrosion control methods.

(a) See Appendix A for drum specifications.

(b) Operated for DOE by Battelle Memorial Institute. 


\section{CONCLUSIONS AND RECOMMENDATIONS}

Corrosion rate estimates indicate that actual penetration of the barrels due exclusively to atmospheric corrosion probably will not occur within the 20-year specified recovery period. However, there is sufficient uncertainty in the available data to prevent a clear-cut statement of the corrosion rate at a specific site. Laboratory and site tests are recommended prior to drawing definite conclusions.

If the combined Rozenfeld-Kure Beach (Rozenfeld 1972; Angeaman and Rankin 1977 ) estimate of $20 \mathrm{mils}$ uniform corrosion in 20 years is accurate, there should be no problems with the structural integrity of the barrels since this represents only one third of their nominal thickness. However, the Idaho National Engineering Laboratory (INEL) Transuranic Storage Cell Penetration and Inspection report (Bishoff 1979) and observations of barrels outside the modules at the Hanford site both show increased corrosion occurring on the lids and points where the barrels contact the ground. Significantly, corrosion problems at INEL occurred before the use of their air support weather shield and stopped as soon as the shield was put into use, which indicates that eliminating exposure to the outdoors should be sufficient to reduce corrosion induced by rainfall or wind-borne particles.

The following suggestions for corrosion reduction are given in order of ascending cost of application.

As a minimum first step, barrel levels within the modules should be separated by slats rather than plywood sheets, which trap dirt and moisture on the lids and preclude any chance of them being washed out or dried off. The use of slats would permit airflow for drying the tops of the barrels.

INEL has had some success in slowing corrosion by stacking barrels on their sides (Legault and Preban 1975). While this technique did reduce the rate of corrosion on lids, it seemed to aggravate problems where the bottom level of barrels contacted the ground. 
The most significant single modification for improving the performance of barrels involves protecting them from exposure to the weather prior to burial. An inexpensive means of doing this is illustrated in this report.

Vapor phase inhibitors would be of nominal cost but would quite possibly have only marginal utility because they require periodic replenishment and careful placement throughout the module. Surface-coating type inhibitors would involve a barrel-by-barrel application. Appendix B notes some commercially available inhibitors.

Galvanized barrels are a low-cost potential solution used effectively at the Savannah River Laboratory (SRL). This procedure was recently accepted for use at Hanford.

Convective ventilation of the modules after burial might be worthwhile for reducing corrosion. It is expected that humidity and temperature extremes would be reduced by such a technique.

Stainless stee1 (SS) drums are used at Oak Ridge National Laboratory (ORNL), but it is expected that the $\$ 200$ per barrel price is not justifiable at Hanford when other options could provide equal protection at a lower cost.

In conclusion, corrosive failure of TRU storage barrels could be mitigated by low-cost application of galvanized barrels, preburial weather shielding, and conversion from continuous plywood to wooden slats between stacked levels. 


\section{SYSTEM DESCRIPTION}

The waste-containing drums rest on asphalt pads running roughly 100 meters long by 7 meters wide; the pads are set into a trench 5 meters deep (see Figure 1). Each pad is progressively filled with "modules" containing 576 barrels stacked upright $12 \times 12$ on the base and four layers high. Each of the four layers is separated by plywood; and when the module is completed, the top layer is covered by plastic sheeting that extends to the ground on all sides. The completed module is covered with one to two meters of overburden. Since typically two modules will be completed per year, the first barrels will be in place and exposed to the outdoor environment for as much as 6 months before the last barrel is in place and the module is covered. 


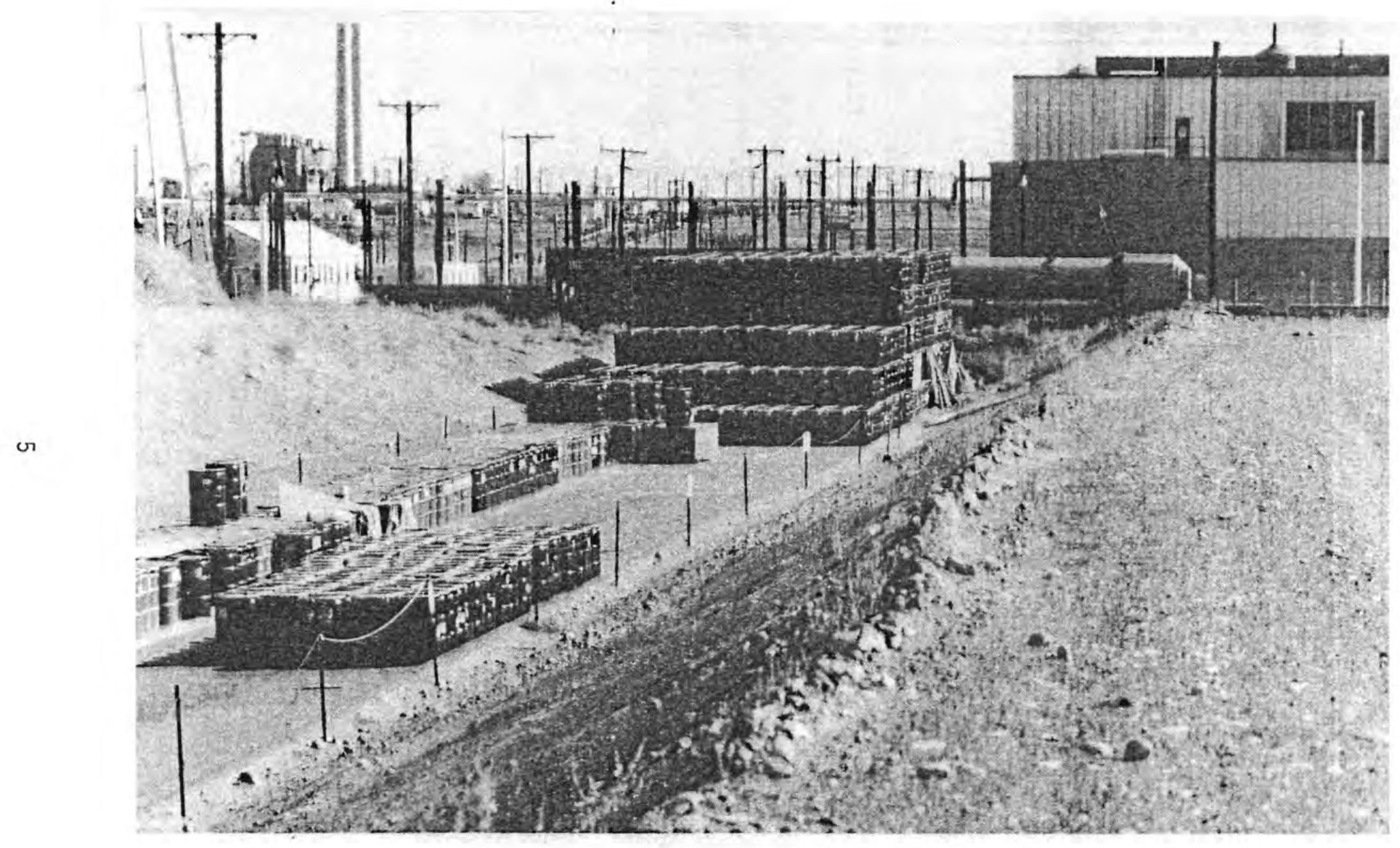

FIGURE 1. Portion of a Transuranic Waste Pad 


\section{FACTORS DETERMINING ATMOSPHERIC CORROSION RATES}

Drums at the Hanford TRU sites have two distinguishably different conditions under which corrosion can take place. The first occurs before the modules are filled, while the metal is exposed to cyclic atmospheric conditions; and the second occurs after burial, when environmental conditions become more stable. Under both of these conditions, the factors determining corrosion rates are humidity, atmospheric pollutants, and temperature.

Prior to burial deposits of atmospheric contaminants such as dust and rain are undoubtedly the more important factor in initiating corrosion.

\section{HUMIDITY EFFECTS}

The actual water content of the air, specified as pounds of water per pound of dry air, is the absolute humidity. The controlling factor for humid$i$ ty effects of atmospheric corrosion is the relative humidity (RH), which is defined as the ratio of the amount of water supported in the air to the maximum amount that could be supported at that temperature, expressed as a percent. Independent papers (Barton and Bartonova 1970; Bailey ${ }^{\circ} 1978$ ) specify 60-80\% RH as a critical humidity above which atmospheric corrosion becomes significantly more rapid.

Rozenfeld (1972, p. 106) addresses this discrepancy by constructing a curve of the dependence of the corrosion rate on $\mathrm{RH}$ from the corrosion-time curve (see Figure 2). The curve in the figure shows a marked increase in corrosion rate at the critical humidity lying between 60 and $70 \%$ RH--the primary critical point; a secondary critical point occurs at $80 \% \mathrm{RH}$. Although visible corrosion can be observed only above $70 \% \mathrm{RH}$, a sharp change in behavior begins at $60 \% \mathrm{RH}$. When $80 \% \mathrm{RH}$ is reached, the metal deteriorates rapidly.

Rozenfeld also explains that at high RHs corrosion develops rapidly and increases linearly with time. If RH is gradually increased up to $50 \%$, no surface changes appear, even after long exposure. Light traces of corrosion appear after a period of weeks at $70 \% \mathrm{RH}$. After the initial acceleration of the 


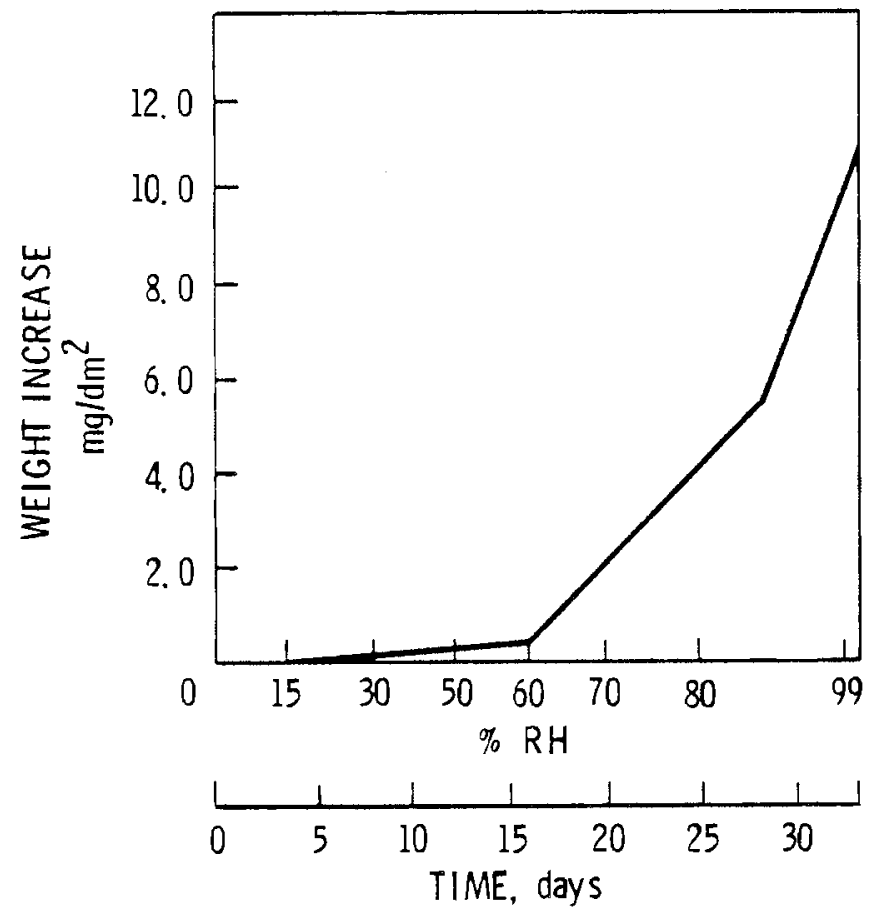

FIGURE 2. Weight Gain as a Function of Percent of Relative Humidity and Time

corrosion process, retardation sets in at extended exposure times. The total corrosion effect is 2 to 3 times less with gradual increases in RH than it is with constant high humidity. This difference is explained by the stability of the initial oxide film during the period prior to obtaining the critical $\mathrm{RH}$.

Apparently only adsorption of moisture occurs at low RH and this is incapable of producing water films of sufficient thickness that corrosion rates become significant. At slightly increased RH corrosion products form that are of a gel-structure in which the water is not in a free state. As RH increases, free spaces in the corrosion products begin to fill up with water so that the liquid penetrates freely to the metal surface.

The assumption is made that the position of the primary critical humidity depends on the relationship between water vapors and contaminants in the atmosphere while the secondary critical humidity depends on the ability of the corrosion products to absorb and retain water vapors (Rozenfeld 1972, p. 107). 
If the humidity is increased above the critical point and subsequently lowered, Speller (1951) implies that it must fall to $30 \%$ or less before the corrosion rate will aga in become inappreciable.

The effective reduction of corrosion by humidity control will evidently only be achieved by the continuous reduction of humidity to below $70 \%$.

\section{ATMOSPHERIC CONTAMINANTS}

The presence of water vapor in the air by itself (regardless of the amount) does not cause significant corrosion. As long as the air-vapor mixture is clean, the rate of corrosion of clean iron increases only slowly with increasing RH. If a small amount of pollutant, such as $\mathrm{SO}_{2}$ (which rapidly forms $\mathrm{H}_{2} \mathrm{SO}_{4}$ ) or $\mathrm{NaCl}$, is introduced, the corrosion rates increase dramatically at the critical humidity due to increased conductivity.

The role played by these pollutants is usually attributed to their impairment of the protective properties of an initial oxide film.

Corrosion is also affected by solid particles that settle onto the metal from the air. These fall into three broad categories:

- corrosion-active particles, such as mineral salts, which are capable of dissociating into ions in water to initiate the formation of corrosion products through increased conductivity of the electrolyte

- noncorrosion-active particles that are capable of absorbing active gases, such as coal particles, in industrial atmospheres to promote corrosion by absorbing $\mathrm{SO}_{2}$

- neutral particles not given toward absorption, such as crystalline silica, whose presence produces crevices in which anodic metal ionization takes place more rapidly than when there is free access of oxygen (Rozenfeld 1972, p. 119).

Particularly relevant to the Hanford site is dust and wind-blown soil that settles onto the sunken lids of the waste barrels. This material probably incorporates all of the mechanisms of surface contamination described above. The easiest and most obvious method to reduce this type of corrosion is 
careful cleaning of the drums prior to long-term burial. This, however, would be a tedious and costly procedure that is not completely effective.

\section{TEMPERATURE EFFECTS}

Corrosion reduction by temperature control is not easily applicable to the TRU pad system because of the inaccessibility of the module once it is covered. However, atmospheric corrosion rates are strongly influenced by temperature.

In the absence of any complicating reactions, corrosion rates tend to increase with increasing temperature in accordance with the laws of diffusion and chemical kinetics. For corrosion processes governed by a chemical reaction rate, the corrosion rate will generally increase by $7-10 \%$ per centigrade degree of temperature increase. For corrosion governed by diffusion, the rate wi11 increase by $1-3 \%$ per degree (Rozenfeld 1972, p. 119).

Apparently separation between the kinetic and diffusive mechanisms of corrosion occurs at the critical point. For $\mathrm{RH}$ below $70 \%$ the kinetics process governs because the electrolyte film is not thick enough to limit diffusion of oxygen and ions.

Increasing temperature will cause a decrease in RH that will ultimately overpower the temperature effect when moisture transfer from the barrel to the surrounding atmosphere removes the electrolyte layer. It will, however, be required that the $\mathrm{RH}$ be 1 owered to $30 \%$ or less before the film is sufficiently reduced to slow corrosion to negligible levels.

\section{CORROSION RATE ESTIMATES}

Legault and Preban (1975) contend that the atmospheric corrosion of lowalloy steels in industrial environments can be estimated by an equation of the form

$$
\Delta W=K t^{N}
$$


where $K$ and $N=$ constants

$$
t=\text { exposure time in years }
$$

$\Delta W=$ the average cumulative penetration depth in mils.

Evaluating $N$ and $K$ requires a complete statistical analysis to write equations in terms of alloy composition.

For a typical 1010 carbon steel, $K$ is determined as 1.72 and $N$ as 0.427 . Accordingly, the estimated penetration after 20 years of exposure to an industrial environment is $6.8 \mathrm{mi} 1 \mathrm{~s}$. With a nominal barrel thickness of $59.8 \mathrm{mi} / \mathrm{s}$ (see Appendix A), this represents a penetration of $11 \%$ (minimum barrel thickness of 53.3 mils yields an estimated maximum penetration of $13 \%$ ).

The following assumptions were made in this description of atmospheric corrosion:

- Environmental pollutants remain essentially constant.

- Weather patterns and thus RH and temperatures tend to average out in the long run.

- Corrosion is general in nature rather than localized.

The first two assumptions are probably acceptable, but the third is problematic. Damaged paint coatings, crevice corrosion, puddling, or a number of other factors could all initiate a more severe local attack.

Rozenfeld's (1972, p. 148) tabulation of the effect of carbon content on the atmospheric corrosion of steel shows a corrosion rate of 177.5 microns per year ( 7.0 mils per year), indicating that penetration of the Hanford storage barrels would occur during the ninth year. Since this figure is given without elaboration, it is impossible to tell whether this high rate represents data from laboratory work or exposure of metals to highly corrosive marine or industrial environments.

Kochen (1974) conducted 60-day corrosion tests on mild steel in $38^{\circ} \mathrm{C}, 95 \%$ $\mathrm{RH}$ air. His results showed a 0.04-mil penetration per year, corresponding to less than $2 \%$ penetration of the Hanford barrels over 20 years. This test was run to compare the performance of two comercially available inhibitors. While the samples cited were untreated, it is reasonable to assume that the 
universally low corrosion rates are due to clean laboratory conditions that are not directly applicable to atmospheric conditions.

In a 10-year test at Kure Beach, North Carolina--a very corrosive marine environment--corrosion rate estimates of carbon steels ranged from $55 \mathrm{mils}$ in 20 years at an $80-\mathrm{ft}$ distance from the beach to $30 \mathrm{mils}$ at $800 \mathrm{ft}$ (Angeaman and Rankin 1977). Although these rates are high, they do represent actual performance tests in an outdoor environment. If the Hanford site can be classified as semirural, Rozenfeld (1972, p. 91) indicates that the rates might be reduced by as much as one third of the 800-ft rate at Kure Beach--down to 7-20 mils in 20 years or $11-33 \%$ of the total metal thickness. 


\section{STORAGE SYSTEMS AT OTHER FACILITIES}

OAK RIDGE NATIONAL LABORATORY (ORNL)

At the ORNL storage site mild steel drums failed the 20-year life criteria on preliminary use due to atmospheric corrosion; the drums were replaced by drums of 304 SS (the hex head locking bolt is 303 SS to minimize galling). The body, cover, and bottom are 16 gauge while the bottom edge reinforcing ring is 12 gauge. The drums, which cost $\sim \$ 200$ each are stored in a $40 \times 60-f t$ concrete block structure that is approximately $85 \%$ underground.

The performance of this system appears to be adequate to meet the 20-year barrel life criteria.

\section{LOS ALAMOS SCIENTIFIC LABORATORY (LASL)}

Steel drums coated with a commercial inhibitor (Texaco Compound L) are used for TRU waste storage at LASL.

To evaluate the performance of both the regular drums and some experimental types, one column of four has been left vacant in a module. This exposes roughly half of four adjacent barrels on each level for inspection. Metals and coatings are scheduled to be examined in 1981.

RH within the module is estimated to be around $90 \%$, but no estimation is made as to the useful lives of the barrels under these conditions.

SAVANNAH RIVER LABORATORY (SRL)

Department of Transportation (DOT) -17C galvanized drums have been used since 1974 at SRL with apparently satisfactory results. The drums are stored at ground level and are covered first by plastic sheeting followed by approximately $4 \mathrm{ft}$ of earth.

The barrels were examined after 1 year and it was estimated that they should last from 15 to 40 years under these conditions. 
Empty barrels are stored indoors until filled; they are then set outside prior to covering and are exposed to the environment for only a matter of weeks.

\section{IDAHO NATIONAL ENGINEERING LABORATORY (INEL)}

At INEL steel drums are used in pads under much the same conditions as at Hanford. However, rather than allowing the drums to be exposed to the weather before burial, the containers are stacked inside a commercially available air support weather shield, which is an air-inflated fabric structure designed to withstand winds up to $160 \mathrm{~km} / \mathrm{h}$ and snow loading up to $150 \mathrm{~kg} / \mathrm{m}^{2}$. This shield has been successful in reducing moisture accumulation and resultant rust. The structure was installed for around $\$ 300,000$ and has an estimated life of 5 years.

INEL also concludes that barrels stacked on their sides perform better than those stacked upright because less flat surface exists for the collection of moisture. Black bituminous base paint also appears to be more resistant to a damp environment than the white alkalyd that is available. 


\section{DISCUSSIONS ON CORROSION CONTROL}

\section{INHIB ITORS}

Inhibitors--substances introduced into an environment in small concentrations--function to slow corrosion by:

- adsorbing as a film onto the surface of a corroding material

- inducing the formation of a thick corrosion product

- changing the characteristics of the environment, either by producing protective precipitates or removing or inactivating an aggressive constituent (Hamner 1973).

Vapor phase inhibitors are applicable for TRU pad environments. This technique transmits inhibitors by vapors from some source onto the metal surface. The inhibitors themselves are crystalline solids whose vapors expand within an enclosed space.

Saturation of the protected volume occurs most rapidly with materials of higher vapor pressure, but in actual application it is preferable to use less volatile inhibitors so that protection is longer lasting.

Vapor phase inhibitors have the advantages that they are easy to use, comparatively inexpensive, and reasonably effective against atmospheric corrosion. The disadvantages are that their radius of protection is rarely over 2 meters and the length of protection is rarely over 2 years. This means that within the TRU pad there must be several scattered deposits of the inhibitor and there must be a means of adding more as time goes on.

\section{EXPOSURE}

It would be very beneficial to assure that barrels do not stand uncovered outdoors before burial. Cyclic weather changes and resulting surface contamination establish favorable conditions for the initiation of corrosion. It is recommended that the containers either be individually covered as they are stacked or be kept out of the weather until a sufficient number have been filled to complete a module. In any event the barrels should be clean and dry at the time they are buried. 
To this end a shelter as simple as that shown in Figure 3 could suffice. While this structure is not easily adaptable to environmental controls for dehumidification or forced air circulation, it will suffice to protect the barrels from extreme sunlight, airborne pollutants, and rainfall.

The fabric that is now used as the final covering before burial could be used and clipped into place for intermediate covering. The framework should be of sufficient height to provide clearance for installation of the top level of barrels. At the completion of a module the fabric would be unclipped and the framework pulled out of the ground and carried to the next location.

\section{DRUM MATERIALS}

On the basis of experiences at SRL and ORNL it appears that either DOT-17C nonpainted galvanized drums or DOT-17H 16 gauge 304 SS drums would be preferable to the mild steel presently used. In 1979, RHO notified DOE that they would begin using DOT-17C nonpainted galvanized drums as soon as their onhand supply of mild steel drums was depleted.

\section{CORROSION MONITORING}

The two most relevant parameters for estimating corrosion-inducing conditions within a module are temperature and RH. A knowledge of the distribution of these two conditions would allow estimation of the performance of the metal from published corrosion rate data. Representative areas of the vapor space surrounding the barrels would have to be probed with leads running up through ventilation tubes.

Corrosion meters, either of the electrical resistance or ultrasonic variety, would be of great use and could be located throughout many modules or concentrated in one to provide a direct indication of the extent of corrosion.

\section{ENVIRONMENTAL CONTROL AFTER BURIAL}

Convective or forced air ventilation in the modules could be used to eliminate the extreme conditions that are possible in a closed cell. Air exchange 


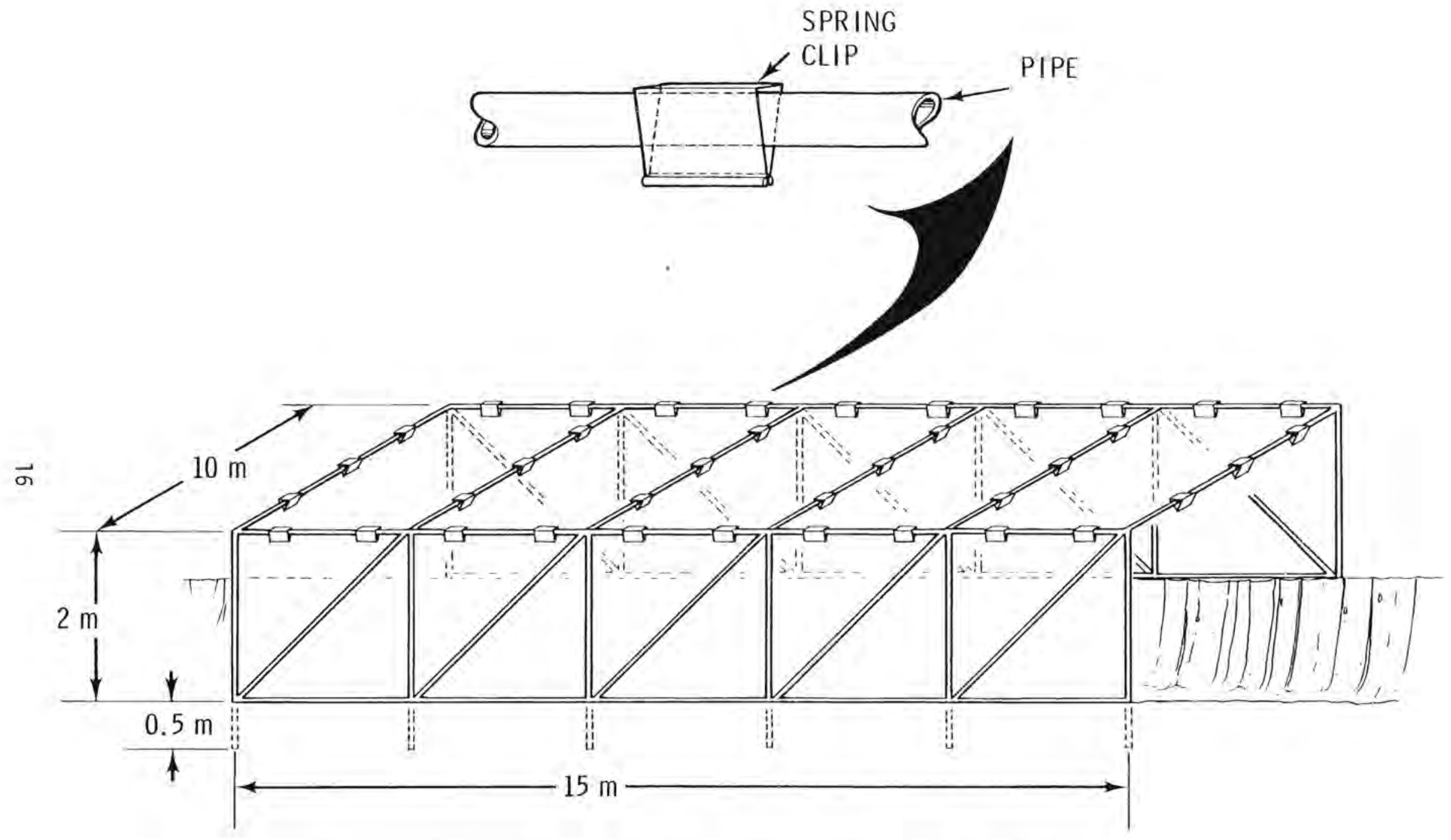

FIGURE 3. Conceptual Dust Shield for Transuranic Pads During Loading 
by blowers is advantageous because circulation can be limited to times when outside conditions are ideal and because inhibitors can be readily introduced into the incoming air.

To promote circulation of air around the tops and bottoms of the barrels, the plywood sheets presently being used to separate levels could be replaced by wooden slats to permit surface drying. 


\section{REFERENCES}

Adams, L. E., et a1. June 1979. Environmental Surveillance Report for the INEL Radioactive Waste Management Complex. TREE-1357, EG\&G Idaho, Inc., Idaho Fal1s, Idaho.

Angeaman, C. L., and W. N. Rankin. 1977. "Durability of Containers for Storing Solidified Radioactive Waste." DP-MS-79-66, Savannah River Laboratory, South Carolina. Presented at Corrosion/77, National Association of Corrosion Engineers Meeting, San Francisco, California, March 14-18, 1977.

Barton, K., and Z. Bartonova. 1970. "Der Begriff Kritische Feuchtigkeit beim atmospharischen Rosten Von Stahl" (The Concept of Critical Humidity on the Atmospheric Rusting of Steel). Werkstoffe und Korrosion 21 Jahrgang, Heft 2/1970, p. 85-88.

Barton, K., and V. Merek. 1970. "Einfluss des entstehenden Rostes auf den Verlauf der atmospharischen Korrosion von Stahl" (Effect of Developing Rust on the Progress of Atmospheric Corrosion of Steel). Werkstoffe und Korrosion 21 Jahrgang, Heft 3/1970, pp. 182-184.

Bailey, P. M. June 1978. "Corrosion Prevention by Humidity Control." Product Finishing $31(6): 18-19$.

Bishoff, J. R. January 1979. INEL Transuranic Storage Cell Penetration and Inspection. TREE-1311, EG\&G Idaho, Inc., Idaho Fa11s, Idaho.

des. Brasunas, Anton, ed. Apri1 1971. NACE Basic Corrosion Course. 2nd ed. National Association of Corrosion Engineers, Houston, Texas, ch. 4.

Evans, U. R., and C.A.J. Taylor. 1974. "Critical Humidity for Rusting in the Presence of Sea Salt." British Corrosion J. 1:26-28.

Hammer, N. E. 1973. "Scope and Importance of Inhibitor Technology." Corrosion Inhibitors. National Association of Corrosion Engineers, Houston, Texas, p. 1 .

Harness, J. L., and J. D. McKinney. January 1977. Containment of Transuranic Contamination at the Early Waste Retrieval Project. TREE-1061, EG\&G Idaho, Inc., Idaho Falls, Idaho.

Kochen, R. L. September 1974. An Evaluation of Texaco Rust Proof (Compound L) and WD-40 as Corrosion Inhibitors on Stressed Versus Unstressed Mild Steel in a Humid Environment. FET 940898-111, Dow Chemical Co., Golden, Colorado.

Legault, R. A., and A. G. Preban. April 1975. "Kinetics of the Atmospheric Corrosion of Low-Alloy Steels in an Industrial Environment." Corrosion-NACE $31(4): 117-122$. 
Mansfield, F., and J. V. Kenkel. 1976. "Electrochemical Monitoring of Atmospheric Corrosion Phenomena." Corrosion Science. Pergamon Press, Vol. 16, pp. 111-122.

Matsui, E. S. January 1974. "Performance of Fencing Materials in a Marine Atmospheric Environment." Materials Performance 13(1):17-19.

Miksic, B. A. March 1975. "Some Aspects of Metal Protection by Vapor Phase Inhibitors." Anti-Corrosion, pp. 5-8.

Mohler, J. B. September 1975. "Corrosion of Coated Materials--Part 6." Metal Finishing 73(9):48-51.

Nathan, C. C., ed. 1973. Corrosion Inhibitors. National Association of Corrosion Engineers, Houston, Texas.

Rozenfeld, I. L. 1972. Atmospheric Corrosion of Metals. National Association of Corrosion Engineers, Houston, Texas, p. 91, 106, 107, 119, 136, and 148.

Shreir, L. L. ed. 1963. Corrosion. John Wiley \& Sons, Inc., New York. Speller, F. N. 1951. Corrosion-Causes and Prevention. 3rd ed. McGrawHi11 Book Company, Inc., New York.

Southwe11, C. R., et a1. Ju1y 1976. "Corrosion of Meta1s in Tropical Environments--Final Report of 16-Year Exposures." Materials Performance $15(7): 9-25$.

Towler, 0. Ju1y 1979. Alternatives for Long-Term Management of Defense Transuranic Waste at the Savannah River Plant. DOE/SR-WM-791, U.S. Department of Energy.

Uhlig, H. H., ed. 1948. Corrosion Handbook. John Wiley \& Sons, Inc., New York.

Ulmer, R. C., and J. W. Wood. August 1952. "Inhibitor for Eliminating Corrosion in Steam and Condensate Lines." Industrial and Engineering Chemistry. $44(8): 1761-1790$.

Valand, T: 1971. "Corrosion of $\mathrm{NaCl}$-Contaminated $\mathrm{Fe}$ in Humid Atmosphere of Low $\mathrm{O}_{2}$ Content." Corrosion Science 11:197-207. 


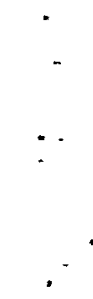


APPENDIX A

SPECIFICATIONS FOR 55-GAL DRUMS FOR STORAGE OF RADIOACTIVE MATERIALS 
APPENDIX A

SPECIFICATIONS FOR 55-GAL DRUMS FOR

STORAGE OF RADIOACTIVE MATERIALS

Purchase specification HWS-8828 REV 4 is a summary of the federal requirements for the steel drums presently used for the storage of radioactive materials. It contains information covered in greater detail in PPP-D-736C, "Interim Amendment to Federal Specification-Drums, Shipping, steel DOT-GA, DOT-6B and DOT-17C" and Title 49 of the Code of Federal Regulations, Section 178.115 .

These documents cover specifications for capacity dimensions, construction techniques, gaskets, finish quality, shipping, and handling.

Copies of HWS-8828 REV 4 are available from Vitro Engineering, Library of National Standards and Specifications. Current copies of the Code of Federal Regulations are available at the Battelle Technical Library, Richland, Washington, or the DOE Legal Library, Richland, Washington. 
APPENDIX B

COMMERCIALLY AVAILABLE INHIBITORS 
APPENDIX B

\section{COMMERCIALLY AVAILABLE INHIBITORS}

Inhibitors are substances introduced into an environment in small quantities that function to slow corrosion. Vapor phase inhibitors have been used in transuranic (TRU) storage pad environments. These inhibitors are easy to use, relatively inexpensive, and reasonably effective against atmospheric corrosion. They are, however, 1 imited in both radius of protection (usually 2 meters) and length of protection (about 2 years).

Surface-coating inhibitors are not particularly applicable to the TRU storage pad environment because they require a barrel-by-barrel application.

The following table lists both vapor phase and surface-coating inhibitors that are commercialiy available.

TABLE B.1. Vapor Phase and Surface-Coating Inhibitors

\begin{tabular}{|c|c|c|}
\hline Inhibitor & Supplier & Comments \\
\hline \multicolumn{3}{|l|}{ Vapor Phase: } \\
\hline NICORA 1579 & $\begin{array}{l}\text { Northern Instruments } \\
\text { Corporation }\end{array}$ & $\begin{array}{l}\text { Powder; } 1 \mathrm{ib} / 500 \mathrm{ft}^{2} \text { of surface. } \\
2-y \mathrm{r} \text { iffe. } \$ 10.60 / 1 \mathrm{~b} \text {. }\end{array}$ \\
\hline Zerust VC6-2 & $\begin{array}{l}\text { Northern Instruments } \\
\text { Corporation }\end{array}$ & $\begin{array}{l}\text { Capsule; } 6-\mathrm{ft} \text { radius of protec- } \\
\text { tion. } 2-y r \text { life. } \$ 336 / \text { case } \\
\text { of } 4 .\end{array}$ \\
\hline VCI -560 & Cortec Corporation & $\begin{array}{l}\text { Powder; } 11 \mathrm{~b} / 228 \mathrm{ft}^{3} \text { of enclosed } \\
\text { space. }\end{array}$ \\
\hline \multicolumn{3}{|l|}{ Surface-Coating: } \\
\hline Moly-White & Sherwin-Williams & $\begin{array}{l}\text { Can replace lead or chromium } \\
\text { pigments in primers. } \$ 1.50 / 1 \mathrm{~b} \text {. }\end{array}$ \\
\hline $\begin{array}{l}\text { Rust Proof } \\
\text { (Compound L) }\end{array}$ & Texaco & $\begin{array}{l}\text { Petrolatum base; penetrating, } \\
\text { water-proof, nonhardening, } \\
\text { self-healing. } \$ 25 / 5 \text { gal }\end{array}$ \\
\hline $\begin{array}{l}\text { WD- } 40 \\
\text { LPS }-3\end{array}$ & $\begin{array}{l}\text { WD-40 Company, } \\
\text { LPA Research Laboratories }\end{array}$ & $\begin{array}{l}\text { Aerosol; glyceryl fatty ester } \\
\text { paraffinic and fatty ester- } \\
\text { base oils. }\end{array}$ \\
\hline
\end{tabular}




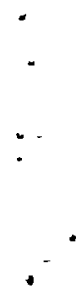


APPENDIX C

WEATHER SHIELDS 


\section{WEATHER SHIELDS}

The Air Support Weather Shield ${ }^{\otimes}$ used at the Idaho National Engineering Laboratory (INEL) was supplied by Irvin Industries at a total installed cost of about $\$ 300,000$. At the end of this structure's 5 -year life it is expected to be replaced by a tension-supported covering also available from Irvin.

To install an air-supported cover of the same type at Hanford would involve an initial unit purchase price of $\$ 122,000$ for a structure $140 \mathrm{ft}$ wide by $300 \mathrm{ft}$ long by $45 \mathrm{ft}$ high $\left(42,000 \mathrm{ft}^{2}\right)$. This includes a fail-safe inflation system consisting of two backward curved nonoverloading blowers powered by commercial electricity or a gas-fired standby engine, one 12-volt battery with selfregulating trickle charger, two outlet back draft dampers, and a solid-state control panel to maintain internal pressure, provide automatic transfer and start up of the emergency engine, and provide retransfer to commercial power. The equipment airlock is $32 \mathrm{ft}$ long by $10 \mathrm{ft}$ wide by $10 \mathrm{ft}$ high.

The tension-supported (Permaspan ${ }^{\circledR}$ ) cover has a unit purchase price of $\$ 112,000$ for a structure $80 \mathrm{ft}$ wide by $210 \mathrm{ft}$ long by $33 \mathrm{ft}$ high $\left(15,800 \mathrm{ft}^{2}\right)$. The overhead roll-up doors are $12 \mathrm{ft}$ square.

\footnotetext{
Registered trademark of Irvin Industries, Lexington, Kentucky.
} 

No. of

Copies

OFFSITE

A. A. Churm DOE Patent Division 9800 S. Cass Avenue

Argonne, IL 60439

27 DOE Technical Information Center

ONSITE

DOE Richland Operations Office

2

H. E. Ransom

Rockwell Hanford Operations

F. Duncan

18 Pacific Northwest Laboratory

T. D. Chikalla

R. L. Dillon

J. R. Divine

S. K. Edler

J. L. Nelson (5)

A. M. Platt

J. Robinson

Technical Information (5)

Publishing Coordination (2) 


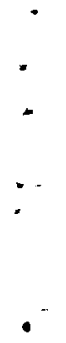

$\therefore$

$\therefore$

:

. 